\title{
The role of tax potential in stimulating the effectiveness of innovation in the digital economy
}

\author{
Olga Maksimchuk ${ }^{10000-0003-4393-6231]}$, Elena Maznitsa ${ }^{10000-0003-1820-172 X]}$, LarisaChizho ${ }^{10000-}$ \\ 0003-2940-8037] \\ ${ }^{1}$ Volgograd State Technical University Institute of Architecture and Construction, 400074, \\ Academicheskaya st., Volgograd, Russia
}

\begin{abstract}
The conditions of the digital economy dictate new challenges in order to correct structural imbalances; answers to these challenges are possible in the format of innovations. Since the beginning of the pandemic, it has become even more obvious that enterprises that have actively introduced innovations, in particular digital technologies and products, have become successful players in all markets. And tax stimulation has always been the most effective tool for innovation in economic activity.The purpose of this study is to substantiate the role of tax potential in stimulating the effectiveness of innovation in the digital economy. The object of research is the tax potential of the territory. The subject of the research is tax stimulation for the efficiency of innovation in the digital economy. The article presents the advantages and disadvantages of the existing tax system for stimulating innovation in Russia, the tax benefits as the main tool for stimulating innovation in the Russian Federation, the proposals for improving legislation on taxes and fees.
\end{abstract}

Keywords: tax potential, factor, effective, stimulation, innovation, digital economy.

\section{Introduction}

In domestic economic science the tax potential of a territory means a group of taxable objects in the current tax system, which are located throughout the country or a specific subject of the federation. This set of all objects of taxation, united by national, sectoral or other criteria, characterizes the resources of the territorial budget revenues per capital [1].The total value of the tax potential determines the possibilities of the government of a country or a subject of the Russian Federation in forecasting and forming the revenue side of the budget, or it is the expected income that the authorities can receive over a specific period of time when using the same taxation conditions throughout the state, which directly and indirectly determine the development opportunities economy of the territory [2].Despite the equal conditions of taxation, the amount of income is determined by the business activity of the objects of taxation in a given territory [3].

Today, in the Russian Federation, there is a discrepancy between significant fundamental developments, the scientific and production base and the underdeveloped innovation sector [4]. There is a predominance of discrepancy between the possibilities of real use of innovations in practice. Significant capital investments are required in the 
material and technical base of organizations. To provide opportunities for the development of the material and technical base for the purposes of innovation, it is necessary to use all financial instruments, and in modern conditions, tax stimulationhas the first place. Tax stimulationcreates the effect of indirect financial support, and it is a set of measures to provide tax benefits and advantages to subjects of economic relations, which, in turn, provide favorable technical conditions for innovation activity [5].

Regional authorities have a significant share in the development of tax incentives. They are observed in the development of technoparks, in the provision of tax benefits in various forms to innovators. At the federal level, the main costs include the introduction of innovations by organizations that have transferred the functions of innovators - for example, «Rosnano» [4]. But at the regional and especially municipal levels, tax stimulation for innovation is practically absent due to the lack of a sufficient amount of budgetary resources. In modern conditions, during the events of the past year in connection with the pandemic have shown, these resources are expected to decrease in many regions. The tax policy reforms are one of the most effective methods to stimulate the economy based on innovation[6].

Objects of taxation, actively introducing innovations, in particular digital technologies and products, in a short time were able to maintain their positions in the market and even increase business activity, many new areas of economic activity were opened when there was decline in the economic activity of traditional industries. The free financial resources, which are freed up when the tax burden decreases, are necessary for the innovative activity of enterprises. It increases the efficiency of innovation in the digital economy based on tax incentives[7].

\section{Materialsandmethods}

The implementation of innovative projects at enterprises is mainly aimed at the production of innovative products with breakthrough features (technological innovations). They can be ordered by the state, other enterprises, or initiated by the entrepreneur. However, business, economic and innovation activity has significantly decreased in the conditions of the crisis, instability due to the pandemic [8].

The main tax incentives are an investment tax credit (for income and property taxes), the use of reduced tax rates and insurance premiums (for residents of special economic zones of a technology-innovative type), accelerated depreciation, a reduction in the taxation base, tax benefits of a simplified taxation system (STS). However, these measures are mainly focused on maintaining a favorable climate for innovation activity. Therefore, there is some uncertainty about the effectiveness of these measures, that requires a change in the tax system. This is important not only in the current conditions of a pandemic, but in general for the formation of a developed innovative economy [9].

Insufficient theoretical and methodological understanding of enterprises' innovation activities as the object of tax regulation is one of the sources of problems that appears during tax incentives [10]. Not all benefits that exist in the Russian Federation can be called effective. So, some measures create questions in terms of their relevance, for example, tax benefits of the STS are ineffective, because the subjects of simplified regimes are small enterprises which rarely use innovations. From the economic point of view, the «accelerated depreciation» benefit is not a tax stimulation mechanism, but a way to reduce an organization's losses from inflation [11].

The provision of a tax credit, depending on the dynamics of the increase of the costs for research and development work, stimulates companies to more actively increase these costs abroad. The practice of levying value added tax (VAT) in Russian conditions does not stimulate innovative activity, innovative products have a long development and 
manufacturing time, that requires their advance payment from consumers. Funds received by way of advance payments and incoming to the current account, are subject to VAT taxation even before the delivery of goods or the performance of work. The solution to these problems should be carried out in the context of a general assessment of the impact of tax incentives in the form of benefits on improving the efficiency of innovation in the digital economy [12]. Incentive measures must be implemented as possible, since Russia's place (Table) in the world innovation rating does not change:

Table. The dynamics of Russia's position in the Global Innovation Index [13].

\begin{tabular}{|l|c|c|c|c|c|c|}
\hline \multirow{2}{*}{ Index } & \multicolumn{6}{c|}{ Years } \\
\cline { 2 - 7 } & 2015 & 2016 & 2017 & 2018 & 2019 & 2020 \\
\hline $\begin{array}{l}\text { Global Innovation } \\
\text { Index }\end{array}$ & 48 & 43 & 45 & 46 & 46 & 47 \\
\hline $\begin{array}{l}\text { Resources of } \\
\text { innovations }\end{array}$ & 52 & 44 & 43 & 43 & 41 & 42 \\
\hline $\begin{array}{l}\text { Results of } \\
\text { innovations }\end{array}$ & 49 & 47 & 51 & 58 & 59 & 58 \\
\hline $\begin{array}{l}\text { Number of countries } \\
\text { participating in the } \\
\text { assessment }\end{array}$ & 141 & 128 & 127 & 126 & 129 & 131 \\
\hline
\end{tabular}

The main reason for the fact that Russia continues to remain far from the leading positions is the quality of the institutional environment and institutional mechanisms for the development and support of innovative business. In modern conditions of the expected reduction in revenues to budgets of all levels caused by the COVID-19 pandemic, tax stimulation for innovation activity, especially in the sector of small enterprises and startups, comesto the first place [13]. The improvement of the institutional environment reduces general uncertainty and risks, thereby reduces the costs of business [14].

The lack of a stable legislative base is a serious problem in modern tax policy. The introduction of frequent amendments and adjustments to the Tax Code of the Russian Federation has an adverse effect on the investment climate and the unwillingness of taxpayers to comply with tax legislation. The stable prevalence of the «fiscal» target of tax collection over the «regulatory» one affectsthe reductionof incentives for entrepreneurial and innovation activity [15].

The tax burden on the real sector of the economy increasesevery year, the products of which form the main part of the country's exports, the gross domestic product (GDP) of the state [16]. The Laffer Curve is an economic indicator that demonstrates the dependence of the growth of budget revenues on the increase in tax rates. An increase in the tax rate, for example, to point $\mathrm{n}$ leads to a loss of incentives to labor and investment, slows down scientific and technological progress (STP), slows down economic growth, that ultimately reduces budget revenues $(\mathrm{n}<\mathrm{m})$. On the contrary, the transition to a lower rate provides an increase in investment, savings, employment, total income and, as a result, an increase in budget revenues. But it is theoretically impossible to find the optimal scale of taxation. Itisdeterminedempirically (Fig.) [17]. 


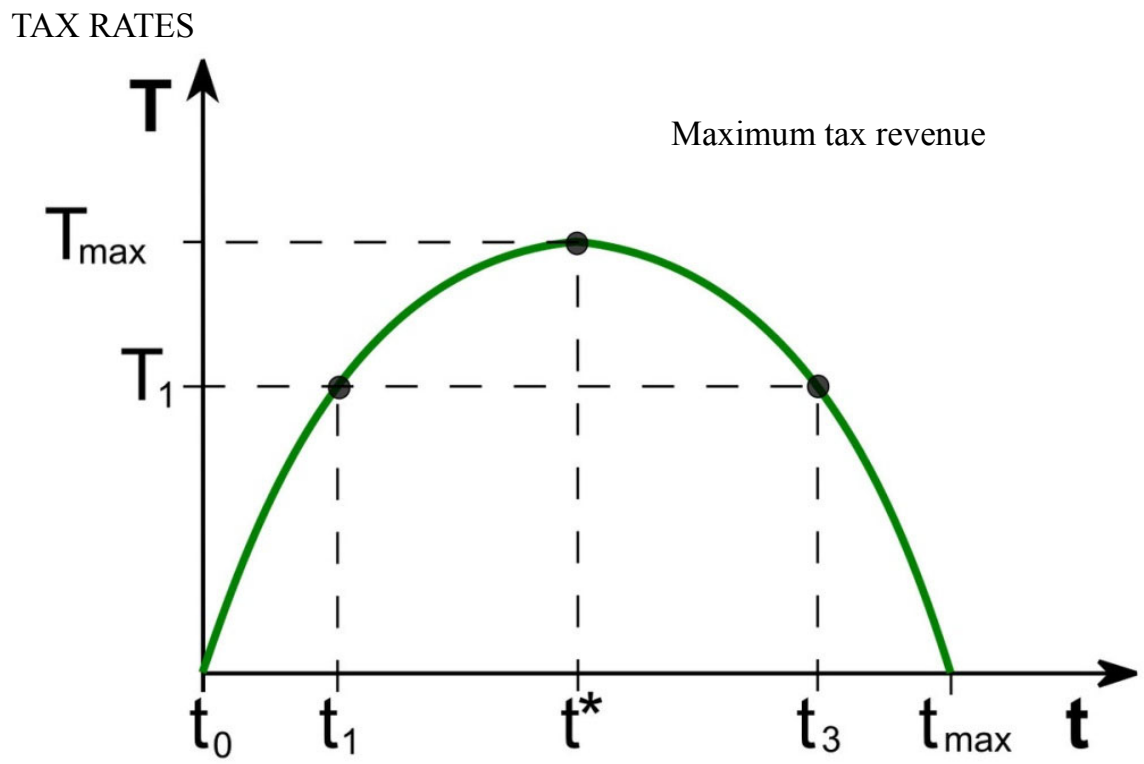

TAX REVENUE

Fig. The Laffer Curve

In accordance with this curve, the growth of rates before a certain point ensures an inflow of budget revenues. But after a certain level, revenues begin to fall, that indicates an excessive tax pressure which takes the business into the shadows. To avoid it, the Ministry of Finance of the Russian Federation needs to make an inventory of all taxes for the proportionality of the tax burden to the current business conditions [18].

\section{Results and discussion}

Despite the high rate of increase in the tax burden on the real sector of the economy, some large organizations use various methods of avoiding taxation. According to statistics from different regions, from $75 \%$ to $80 \%$ of large business, disguised through figurehead, is owned by foreign residents. Therefore,there is the serious problem of depreciation of production assets (more than $80 \%$ ), and tax evasion in offshore zones. There is the trend of the outstripping development of the extractive sector, the sphere of services, the financial sector in relation to the branches of material production. The tax potential to stimulate the effectiveness of innovation in the digital economy is extremely underdeveloped in our country. At the same time, due to strict financial centralization with the dominance of the fiscal interests of the state, combined with a significant tax burden on individuals, small and medium-sized businesses, a situation arises in which a significant share of tax revenues «flows» into the shadow economy [19].

On January 1, 2019, the VAT rate in Russia increased from 18 to $20 \%$. The increase in VAT in Russia brought additional revenues to the country's budget for 650 billion rubles, which is comparable to $0.6 \%$ of the country's GDP.

$2 \%$ increase in VAT in the current conditions is an unfavorable factor for the development of innovations in the digital economy. The increase in the interest rate led to an increase in prices and a decrease in real incomes of the population. It was another failure to the investment opportunities of private businesses. The investor must understand that the 
products and goods will be paid for by the consumer. But, if the income of this consumer falls, then investment programs are naturally revised. A drop in demand also provokes a drop in supply $[19,20]$.

Experience of foreign countries (in Switzerland the VAT rate is $8 \%$, Singapore is $5 \%$, China is $16 \%$, in Australia, Canada, USA, Japan sales tax is charged instead of VAT, at which the average rates for the states of the USA and Canada are 2-15\% and 5-6\%, respectively, in Australia $-10 \%$, in Japan $-8 \%$ ), which have a high innovation index, shows that VAT growth can be ensured by lowering the tax rate. In this case, the increase in tax is facilitated by the expansion of the tax base even at a lower tax rate [21].

Due to an increase in the tax burden, namely, an increase in the mineral extraction tax (MET) until 2021 in connection with the implementation of a tax maneuver, indexation of excise duties and taxes on small businesses in Russia, 668 thousand legal entities were closed over the past year. This critical trend has been observed since 2016. In 2018, one open business accounted for two closed ones. Small business taxes are indexed by increasing the correction coefficients that have been introduced since 2020 for the unified imputed income tax (UTII), the patent taxation system and personal income tax (PIT). And the indexation in 2020 is higher than inflation by almost $5 \%$ compared to 2019 . If it happens from year to year, then the tax burden rises every year. Further, there is an increase in the quasi-fiscal tax burden due to an increase in rates for a number of non-tax payments. Most of the non-tax levies have appeared in the last 7-8 years (environmental levy, payment for negative impact on the environment (EIA), recycling levy, resort levy, obligatory deductions from telecom operators, payment for heavy vehicles, fees for issuing codes for labeled goods) .It can lead to stagnation and further economic recession [22].

In the past 10 years, there has been an increase in taxes in the non commodity sector by 2.6 times, and in the commodity sector by 2.2 times. So, in 2008 , one enterprise of non commodity sector paid about 1.2 million rubles to the treasury, and in 2018 payments reached 3.2 million rubles. At the same time, the number of such enterprises from 2008 to 2018 decreased from 4.7 to 4.2 million, which amounted to $12 \%$. Almost all decrease in the number of enterprises arose due to trade, which is confirmed by 4 times increase in the fiscal burden in the trade sector and a decrease in the number of enterprises by $30 \%$. Therefore, the tax burden has a great influence on the non commodity sector. For the greatest stimulation of the economy, it is necessary to minimize Russia's dependence on oil and gas exports, create a modern non commodity model of economic development, and prevent inflation [23].

In 2016, the Strategy for the Development of Small and Medium Enterprises in the Russian Federation for the period up to 2030 was developed and adopted. In 2017-2018, 82 $\%$ of the Strategy's activities were completed. The state should regulate and support small businesses for the development of new types of activities in the field of innovative industries [24]. The factor influencing the investment attractiveness of the region is the predictability of the business costs through the introduction of the mechanism of state guarantees [24].

\section{Discussion}

Since the beginning of 2020, a special tax regime for the self-employed has begun to operate in 19 regions. Self-employed are people who do not burden the state, they are not registered at the employment center, do not receive benefits, do not hold meetings because of unemployment. This tax is most popular among taxi drivers, IT specialists, web designers, computer foremen, and tutors. However, for many, this tax regime turned out to be unclaimed. They fear that after thereceipt of the official status of self-employed, the volume of claims against them will increase and the costs will increase. To get out of this 
situation, the state should provide for deductions [24]. It is necessary to consider the mechanism for providing an investment tax deduction, which plays an important role in shaping the development of the country's economy. This deduction is allocated to enterprises in order to increase investments in fixed assets for the reconstruction of the park of production assets, but various conditions apply that block the application of this preference. The investment tax deduction is provided to companies only if such a right is granted by the law of the subject of the federation. In addition, regions can limit the maximum amount of deduction from the regional budget, choose the categories of equipment in the industry to which it applies. But, given the difficult financial situation, not all regions have introduced this benefit.

At present time, this preferential mechanism has been introduced in 50 regions. In Moscow, this deduction has been introduced since01.01.2020, it has a maximum deduction amount of $90 \%$, the interest rate for calculating the limit value is $12.5 \%$ and $8.5 \%$. The right to apply the tax deduction is granted to organizations located in the city of Moscow and received the status of a Moscow investor of the first category or the status of a Moscow investor of the second category, with the exception of fixed assets: acquired as a result of reorganization; acquired from legal entities and (or) individuals included in the same group of persons with the taxpayer, in accordance with the legislation of the Russian Federation on the protection of competition; received free of charge; identified as a result of the inventory; partially liquidated [25].

In addition, the existing VAT preferences for businesses are also quite insignificant. It is important that the valueadded taxation of financial transactions have the preferential nature that are exempt from VAT in Russia. Thus, the state stimulates the financial sector without any restrictions and conditions. While in terms of innovation spending, it is necessary to implement a variety of procedures that limit their activity towards innovation. Therefore, it is necessary to have a balance between financial services and the real sector. In addition, in the case of levying VAT on products for which the collection of excise taxes is established, the amount of excise taxes is also included in the tax turnover. And it creates the anomaly double taxation, which also negatively affects the country's economy. The introduction of a sales tax or a reduction in the VAT rate will solve the problem of a large number of intermediaries, which makes it difficult for domestic products to enter world markets.

Moreover, effective interaction between small and large businesses prevents the massive use of special tax regimes by small businesses which are exempt from VAT. For this reason, large enterprises purchase from each other. And the introduction of a sales tax will undoubtedly help solve this problem by stimulating demand and reviving the economy.

State levers of influence on the economy are concentrated at the federal level. The government has all the conditions to develop a high-tech non- commodityeconomy, but it is interested in developing a commodity economy, not a high-tech one. Regional governments have incentives to develop competition, increase labor productivity, and help enterprises to introduce new technologies, but they do not have sufficient instruments of state influence. To improve the economy of the Russian Federation in the context of Western sanctions, the main condition is the transformation of the export- commodity economy into an innovative economy.

For example, in the Volgograd region in April 2020, there are changes in the regional law «On the rate of tax paid in connection with the application of a simplified taxation system» to support business and sustainable development of the economy in the conditions of countering coronavirus infection, according to which more than 6 thousand preferences are expected to be received by regional organizations and individual entrepreneurs. New tax rates apply to organizations and entrepreneurs in the following areas:

- passenger and freight transport;

- tourism, hotel, spa and exhibition business; 
- consumer services;

- additional education and childcare;

- art, sports, recreation and entertainment.

The purpose of these tax measures is to reduce the burden on small and medium-sized businesses, to preserve jobs and toensure payment of wages in the context of the coronavirus pandemic [26]. But tax incentives for innovation should be applied under all conditions. The predictability of business development costs by introducing a mechanism of state guarantees, which could be a reliable support for Russian and foreign residents, could create confidence in the safety of their business activities, is an important factor that has a positive impact on stimulating innovation in the digital economy.

The growth in the competitiveness of Russian enterprises, due to a decrease in the tax burden and the prevalence of various benefits, has a beneficial effect on further stimulating economic growth in Russia. Tax reductionis the most important stimulus for effective economic development. Effective stimulation of innovation in the digital economy is achieved by easing the tax burden on corporate business. The experience of industrialized countries shows that a stable state base finds a place only if the tax potential is observed, which stimulates the effectiveness of innovation in the digital economy [27].

\section{Conclusions}

The current benefits do not sufficiently stimulate the innovative economy, which leads to tax evasion. To increase business activity and the efficiency of innovations in the digital economy, direct (allocation of grants, presentation of state awards, awarding of honorary titles) and indirect assistance from the state is necessary through the provision of tax benefits. The launch of innovative projects revitalizes the market, increases the business activity of organizations, forms new production chains, it creates conditions for effective activity and the new objects of taxation [28]. Tax benefits are the main condition for the growth of the tax potential of the territory in modern conditions and stimulating innovation in the digital economy.

In our opinion, the budget should receive all the additional revenues. Work in this direction is already going, $2 \%$ of the income tax of wealthy Russians brought 1.8 billion rubles to the federal budget in January 2021. According to the principle of collection on a progressive scale, the tax was paid by Russians who earned more than 5 million rubles in January. Incomes of this level were officially received by no more than 20 thousand Russians. The total volume of revenues exceeded 92 billion rubles. Thus, in Russia, there is a new law about increase the rates of personal income tax (PIT) from $13 \%$ to $15 \%$ on income exceeding 5 million rubles per year [28].

\section{References}

1. V. V. Ivanov, N. V. Pokrovskaia, N. A. Lvova, Tax potential concepts, in Proceedings of the 5th International Conference on Accounting, Auditing, and Taxation, ICAAT 2016, 139-145 (2016)

2. V. V. Markov, Tax benefits as a way to stimulate innovation: assessing the feasibility and budgetary effectiveness of their application $(204,2010)$

3. Tax benefits for small and medium-sized businesses and entrepreneurs adopted in the Volgograd region [Electronic resource] URL: https://tass.ru/ekonomika/8184459 (last accessed: 03.03.2021)

4. Yu.bN. Tret'yakova, Tax incentives for innovation in the Russian Federation, Young scientist, 7(87), 499-502 (2015) 
5. L. Bryantseva, N. Shishkina, A. Tolstykh, O. Mukhina, Optimization of taxation of business entities in the context of sustainable development of the region, IOP Conference Series: Materials Science and Engineering, 890, 012192 (2020) DOI: 10.1088/1757-899X/890/1/012192

6. Nanotechnology is on the defensive [Electronic resource] URL: https://www.kommersant.ru/doc/4595433?utm_source=yxnews\&utm_medium=desktop $\& n w=1607003696000$ (last accessed: 01.03.2021)

7. Hyun, Hea-Jung, Do Small and Medium Enterprises Gain from Offshoring? Journal of Korea trade, 11, 1-20 (2015)

8. Resolution of the Government of the Russian Federation of April 15, 2014 N 316 «On approval of the state program of the Russian Federation» Economic development and innovative economy» (with changes on March 31, 2020 No. 376) [Electronic resource] URL: https://www.economy.gov.ru/material/dokumenty/postanovlenie_pravitelstva_rf_ ot_15_aprelya_2014_g_n_316.html

9. A. Romanova, E. Ilina, Operational services management in the context of sustainable development of intellectual technologies, IOP Conference Series: Materials Science and Engineering, 890, 012183 (2020) DOI: 10.1088/1757-899X/890/1/012183

10. A. V. Vasina, A model for the implementation of strategic management of the parameters of innovative projects at enterprises, Actual problems of economics and management, 2(22), 15 (2019)

11. N. Lupton, P. Beamish, Developing Global Service Innovation Capabilities How Global Manufacturers Address the Challenges of Market Heterogeneity, Knowledge Management Research \& Practice, 14 (1), 150-157 (2016) DOI: 10.1057/kmrp.2014.25

12. D. M. Stepanenko. Tax incentives for innovation: foreign experience and Russian realities, Bulletin of the Ural Institute of Economics, Management and Law, 2. 36-46 (2010)

13. Global Innovation Index-2020 clarifications [Electronic resource] URL: https://issek.hse.ru/news/396120793.html (last accessed: 10.03.2021)

14. O. S. Boikova, On the concept of institutional mechanisms for support and development of innovation, Actual problems of economics and management, 1(13), 5 (2017)

15. V. G. Lizunkov, V. I., Marchuk, E. Yu. Malushko, Economical and Managerial Competencies of Bachelors in Mechanical Engineering, European Proceedings of Social and Behavioural Sciences, 19, 456-463(2017)

16. What is the tax burden: clarifications [Electronic resource] URL: https://znatokprava.ru (last accessed: 03.03 .2021)

17. M. G. Minin, E. V. Politsinskaya, V. G. Lizunkov, Readiness of Technical University Students to Entrepreneurship Activity, Vysshee obrazovanie v Rossii [Higher Education in Russia], 28(10), 83-95(2019)

18. D. A. Golovenkin, Shadow economy and economic security - causation and interaction features, Actual problems of economics and management, 1(21), 12 (2019)

19. The Federal Tax Service clarified the procedure for applying the VAT tax rate of 20 percent since January 1, 2019 [Electronic resource] URL: https://www.nalog.ru/rn74/news/tax_doc_news/7907660 (last accessed: 28.01.2021)

20. Preferential VAT rates [Electronic resource] URL: https://finance.rambler.ru/economics/40114387/?utm_content=finance_media\&utm_me dium=read_more\&utm_source=copylink (last accessed: 03.03.2021)

21. VAT in Russia and in the world. What are the best rates? [Electronic resource] URL: last accessed: 03.03.2021)

22. Tax cuts are doping for the economy [Electronic resource] URL: https://www.znak.com/2019-11-21 (last accessed: 03.03.2021)

23. E. E. Koba Actual problems of small business functioning in Russia, Actual problems of economics and management, 1(25), 91 (2020) 
24. T. Yu. Ksenofontova, Formation of public-private instruments for increasing the level of innovativeness of industrial products, Actual problems of economics and management, 4(20), 70 (2018)

25. What is «professional income tax» [Electronic resource] URL: https://npd.nalog.ru (last accessed: 03.03.2021)

26. Investment tax deduction by region [Electronic resource] URL: https://its.1c.ru/db/taxprib/content/12581/hdoc (last accessed: 01.03.2021)

27. L. Keeley, R. Pikkel, B. Quinn, H. Walters, Ten Types of Innovation: The Discipline of Building (JohnWiley\&Sons, 276, 2013)

28. E. M. Maznitsa, O. V. Maksimchuk, M. K. Belyaev, Innovative technologies and solutions in the urban economy of the regions, European Proceedings of Social and Behavioural Sciences, 104, 75, 600-608 (2020) DOI: 10.15405/epsbs(23571330).2020.xx.10 